\title{
Prescribed Burning of a Festuca-Stipa
} Grassland

\author{
ARTHUR W. BAILEY AND MURRAY L. ANDERSON
}

\begin{abstract}
Highlight: The Festuca-Stipa grassland community was found to be well adapted to surviving a single prescribed burn. Coverage of rough fescue was reduced from one to three growing seasons after fire depending upon season burned and stage of growth. Spring burning benefited the production of seed heads in western porcupine grass but fall burning reduced its cover and production of seed heads. Annual herbage production was neither increased nor decreased if burning occurred when plants were dormant. Species composition shifted in favour of perennial forbs for at least 3 years after a burn.
\end{abstract}

Fire was an important ecological factor on Canadian prairie rangelands prior to white settlement. Fire frequency increased during the 1880 to 1920 era of settlement and railroad building (Moss 1932; Nelson and England 1971). Fires were considered such a hazard in the late 1800's that they had an important influence on the development of legislation and local government (Nelson and England 1971). The suppression of fire was so successful that these grasslands have existed without frequent fire for about 70 years.

The fescue grasslands of central Alberta and Saskatchewan are part of the aspen parkland. The degree of dominance of rough fescue (Festuca scabrella) ${ }^{1}$ varies with climate, soil, and grazing pressure. Rough fescue is the dominant in the black soil zone on the northern (moist) fringe of the aspen parkland (Coupland and Brayshaw 1953). This grassland is almost pure rough fescue but it has virtually disappeared because of either cultivation or tree encroachment. In most of the aspen parkland, the remaining grasslands are in the more arid dark brown soil zone where rough fescue is a codominant with western porcupine grass (Stipa spartea var. curtiseta).

Moss (1932) observed that burning had effectively stopped tree advance in the Alberta aspen parkland. He predicted that in the absence of fire, succession would soon produce a considerable extension of the aspen (Populus tremuloides) forest. The rate of brush encroachment into, and the elimination of, the rough fescue grassland has increased (Maini 1960; Johnston and Smoliak 1968; Bailey and Wroe 1974; Scheffler 1976). However, the effect of lack of fire on the remaining rough fescuewestern porcupine grass community is unknown.

The purpose of this study was to determine the effect of spring and fall prescribed burning on species composition and pro-

\footnotetext{
Authors are professor of range management and research assistant, Department of Plant Science, University of Alberta, Edmonton T6J 2El. At present the junior author is supervisor, grazing reserves, central region, Alberta Department of Energy and Natural Resources, Edmonton. This research was supported by grants from the Alberta Cattle Commission, Alberta Agricultural Research Trust, and Canada Agriculture to the senior author.

Manuscript received June 23, 1977.
}

ductivity of the rough fescue-western porcupine grass community.

\section{Methods}

The study area was located at the University of Alberta Ranch in Section 4, Township 47, Range 11, west of the 4th meridian, $158 \mathrm{~km}$ southeast of Edmonton, Alberta. The topography was moderate to strongly rolling, known locally as knob and kettle topography. The dark brown and black chernozemic soils ${ }^{2}$ have developed from glacial till and have a loam texture. Average annual precipitation was $36 \mathrm{~cm}$ with $20 \mathrm{~cm}$ occurring during the May to August growing season. The July and January mean temperatures were $17^{\circ} \mathrm{C}$ and $-19^{\circ} \mathrm{C}$, respectively. The study area had been lightly grazed for 10 years.

All prescribed burns were located within $100 \mathrm{~m}$ of one another on similar parent material, soils, relief, and vegetation. The burns were conducted on a 3-ha area on May 8, 1970, on a 5-ha area on October 3, 1970, and on a 20-ha area on May 11, 1971. The burns were set as headfires although certain parts of each area were burned by backfires. There were no replications.

\section{Vegetation Measurements in the Spring 1970 Fire}

Permanent plots were set out in the burned and unburned treatment areas. A distance of $2 \mathrm{~m}$ was left unsampled on each side of the fire line to remove the edge effect. The burned and unburned areas were marked off in 2-m wide transects. A $20 \times 50 \mathrm{~cm}$ plot was randomly located and permanently marked in each $2-\mathrm{m}$ segment of a transect. Canopy coverage of all plant species and density of seed heads of rough fescue and western porcupine grass were measured in July 1970, 1971, and 1972. Density of shrub stems was measured in each plot in August 1970, 1971, and 1972. Canopy coverage was estimated following the method of Daubenmire (1968b) using the following canopy coverage classes: (Class number, canopy cover range, class mid-point) Class 1: $0-1 \%(0.5)$; Class 2: 2-5\% (3); Class 3: 6-25\% (15); Class 4: 26-50\% (37.5); Class 5: $51-75 \%$ (62.5); Class 6: $76-95 \%$ (85); Class 7: $96-100 \%$ (97.5).

Vegetation Measurements in the Fall, 1970, and Spring, 1971 Fires

Five $5 \mathrm{~m} \times 7 \mathrm{~m}$ macroplots were randomly selected from a number of possible sites within each of the (a) unburned control, (b) the 5-ha fall 1970 burned, and (c) the 20-ha spring 1971 burned treatments. The control macroplots were randomly selected from similar unburned stands immediately surrounding the burns. Each macropolot was divided into meter-square microplots. A $20 \mathrm{~cm} \times 50 \mathrm{~cm}$ plot was randomly located in each microplot. Canopy coverage estimates were made in July, 1971, for all plant species following the method described above. Also measured was the density of seed heads of rough rescue and westem procupine grass.

Total annual herbage production was measured in September, 1971, by randomly locating three $0.9-\mathrm{m}^{2}$ microplots in each macroplot. The herbage was clipped to ground level, oven dried, and weighed.

2 The Canadian soil classification system is used (Clayton et al. 1977). 
The canopy coverage values wee transformed using the inverse sine prior to the use of analyses of variance tests. Data reported in all tables have been returned to the original percentage scale.

\section{Results}

The weather conditions prior to and during burning are presented in Table 1. Burning was conducted when rough fescue growth was about $10 \mathrm{~cm}$ tall in Burn $1,4 \mathrm{~cm}$ tall in Burn 3 , and after the herbaceous vegetaion had dried in Burn 2. Little precipitation had fallen prior to each burn and seasonal drying weather had been experienced. All burns were conducted under dry conditions where the relative humidity was $25 \%$ or less and winds were moderate. However, gusts of wind ranging from an estimated 33 to $58 \mathrm{kph}$ blew flaming firebrands from shrubs causing one spot fire in Burn 1 and four spot fires in Burn 3. Burn 2 went out of control because of inadequately prepared fire lines and suppression procedures.

Table 1. Weather conditions prior to and during the three prescribed burns.

\begin{tabular}{|c|c|c|c|c|}
\hline Variable & & Burn 1 & Burn 2 & Burn 3 \\
\hline Date of burn & & $\begin{array}{c}\text { May 3, } \\
1970\end{array}$ & $\begin{array}{l}\text { Oct 3 } \\
1970\end{array}$ & $\begin{array}{c}\text { May 11, } \\
1971\end{array}$ \\
\hline $\begin{array}{l}\text { Total precipitation during } \\
\text { previous } 30 \text { days }(\mathrm{cm})\end{array}$ & & 0.4 & 1.8 & 0.3 \\
\hline $\begin{array}{l}\text { Weather conditions during } \\
\text { previous } 7 \text { days: }\end{array}$ & & & & \\
\hline $\begin{array}{l}\text { Mean maximum temperature } \\
\left({ }^{\circ} \mathrm{C}\right) \\
\text { Mean wind speed (kph) } \\
\text { Mean relative humidity }(\%)\end{array}$ & $\begin{array}{l}\text { Kinsella } \\
\text { Kinsella } \\
\text { Edmonton }\end{array}$ & $\begin{array}{l}19 \\
19 \\
44\end{array}$ & $\begin{array}{l}22 \\
16 \\
44\end{array}$ & $\begin{array}{l}18 \\
19 \\
34\end{array}$ \\
\hline
\end{tabular}

Weather on day of burn:

$\begin{array}{lllll}\text { Maximum temperature }\left({ }^{\circ} \mathrm{C}\right) & \text { Kinsella } & 19 & 24 & 25 \\ \text { Mean wind speed }(\mathrm{kph}) & \text { Kinsella } & 23 & 13 & 13 \\ \text { Mean relative humidity }(\%) & \text { Edmonton } & 42 & 47 & 29\end{array}$

Weather during burn:

$\begin{array}{lllll}\text { Wind speed (kph) } & \text { Kinsella } & 35 & 15 & 13 \\ & \text { Edmonton } & 35 & 15 & 15 \\ \begin{array}{l}\text { Maximum gust } \\ \begin{array}{l}\text { Relative humidity (\%) } \\ \text { during the fire }\end{array}\end{array} & \text { Edmonton } & 55 & 15 & 42 \\ & \text { Edmonton } & 25 & 25 & 19\end{array}$

I A steady wind was recorded during the fire

Total canopy coverage in the rough fescue-western porcupine grass community changed only slightly the first growing season after either a spring or fall burn (Table 2). The canopy coverage of grasses and grass-like species decreased while coverage of perennial forbs increased.

The canopy coverage of several species was lower in both burn treatments. Rough fescue coverage was $26 \%$ lower in the spring burn and $6 \%$ lower in the fall burn, while its seed head production declined only after the spring fire. The coverage and seed production of western porcupine grass was reduced by fall burning. Coverage of sedges (Carex spp.) was 19\% lower in the spring 1971 burn treatment. Hooker's oatgrass (Helictotrichon hookeri) and fringed sage (Artemisia frigida) were reduced by both fall and spring burns. The coverage value of several forbs
Table 2. Canopy coverage (\%), density of seed heads (culms $/ \mathrm{m}^{2}$ ) and annual herbage production $(\mathrm{kg} / \mathrm{ha})$ in the unburned, fall burned, and spring burned treatments.

\begin{tabular}{|c|c|c|c|}
\hline \multirow[b]{2}{*}{ Category } & \multicolumn{3}{|c|}{ Season Burned } \\
\hline & $\begin{array}{l}\text { Unburned } \\
(n=175)\end{array}$ & $\begin{array}{c}\text { Fall } \\
(\mathrm{n}=175)\end{array}$ & $\begin{array}{c}\text { Spring } \\
(n=175)\end{array}$ \\
\hline \multicolumn{4}{|l|}{ Vegetation class: } \\
\hline All classes & 280 & 282 & 265 \\
\hline Grasses and grass-likes & 252 & 224 & 200 \\
\hline Perennial forbs & 26 & 54 & 60 \\
\hline Shrubs & 3 & 3 & 6 \\
\hline \multicolumn{4}{|l|}{ Species: } \\
\hline Rough fescue-cover & $84 a^{1}$ & $79 b$ & $62 \mathrm{c}$ \\
\hline- seed heads & $34 a$ & $35 \mathbf{a}$ & lb \\
\hline Western porucpine grass-cover & $86 a$ & $79 b$ & $84 a$ \\
\hline - seed heads & $48 \mathrm{a}$ & $11 \mathrm{~b}$ & $48 a$ \\
\hline Hooker's oatgrass & $18 \mathrm{a}$ & $6 b$ & lb \\
\hline Pasture sage & $3 a$ & $+b^{2}$ & $+b$ \\
\hline Sedge & $54 a$ & $55 a$ & $44 b$ \\
\hline Wheatgrass $^{3}$ & 6 & 4 & 8 \\
\hline Milk vetch ${ }^{4}$ & 4 & 12 & 11 \\
\hline Three-flowered avens & lb & $11 \mathrm{a}$ & $10 \mathrm{a}$ \\
\hline Yarrow & lb & $2 a$ & $4 a$ \\
\hline Blue bur & $\mathrm{Ob}$ & la & $+\mathbf{a}$ \\
\hline Prairic crocus & 7 & 7 & 8 \\
\hline Number of species & 41 & 38 & 37 \\
\hline Annual herbage production & $1180 \mathrm{a}$ & $1145 a$ & $1365 \mathrm{a}$ \\
\hline \multicolumn{4}{|c|}{$\begin{array}{l}\text { 'Values within each row followed by a common letter } \mathrm{a}, \mathrm{b} \text {, or } \mathrm{c} \text { do not differ significar } \\
(P<0.05) \text { using Duncan's multiple range test. }\end{array}$} \\
\hline
\end{tabular}

including prairie sage (Artemisia ludoviciana) increased after both fall and spring burn treatments. Blue bur (Lappula redowski) and wild strawberry (Fragaria virginiana var. glauca) were present in the two burn treatments but were absent from the control. There were no annual forbs.

Annual herbage production at the end of the 1971 growing season was not changed by spring of fall burning (Table 2).

In the 1970 spring burn, total canopy coverage was $19 \%$ lower than the control the first growing season after fire (Table 3 ). One and two years later, total canopy cover was $8 \%$ and $6 \%$ less, respectively, in the burned area. The first year after burning, grass and shrub coverage was less in the burned area while forb coverage was greater. All classes increased in coverage the second year. In the third year, forbs declined while shrubs, grasses and grass-likes increased. The species most detrimentally affected by spring burning were rough fescue, wheatgrasses, and the shrub silverberry (Elaeagnus commutata). Although most forbs benefited from burning, smooth aster (Aster laevis) increased the most. By the second year, rough fescue had recovered considerably but wheatgrasses and silverberry had not recovered to preburn levels. Forb coverage exceeded preburn levels. By the third year, rough fescue had nearly recovered to preburn levels. Sedge coverage declined greatly in the third year in both unburned and burned treatments; frequency remained at $100 \%$ and no obvious change in density was observed.

The 1970 spring burn stimulated reproductive performance in western porcupine grass 1, 2, and 3 years afterwards (Table 3 ). Rough fescue was unaffected because it did not set seed in 1970. 
Table 3. Canopy coverage (\%), and density of seed heads (culms $/ \mathrm{m}^{2}$ ) for three years following the spring, 1970, fire in unburned and burned treatments.

\begin{tabular}{|c|c|c|c|c|c|c|}
\hline \multirow[b]{2}{*}{ Category } & \multicolumn{3}{|c|}{ Unburned } & \multicolumn{3}{|c|}{ Burned } \\
\hline & $\begin{array}{r}1970 \\
(n=30)\end{array}$ & $\begin{array}{c}1971 \\
(n=30)\end{array}$ & $\begin{array}{c}1972 \\
(n=30)\end{array}$ & $\begin{array}{r}1970 \\
(n=34)\end{array}$ & $\begin{array}{c}1971 \\
(n=34)\end{array}$ & $\begin{array}{l}1972 \\
(n=34)\end{array}$ \\
\hline \multicolumn{7}{|l|}{ Vegetation Class: } \\
\hline All classes & 317 & 345 & 281 & 258 & 318 & 264 \\
\hline Grasses & 202 & 204 & 181 & 135 & 162 & 171 \\
\hline Perennial forbs & 18 & 41 & 26 & 43 & 67 & 45 \\
\hline Shrubs & 29 & 44 & 47 & 14 & 17 & 20 \\
\hline \multicolumn{7}{|l|}{ Species: } \\
\hline Rough fescue-cover & 92 & 85 & 83 & 36 & 59 & 75 \\
\hline -seed heads & 0 & 26 & 0 & 0 & 26 & 0 \\
\hline Wheatgrass $^{1}$ & 18 & 26 & 16 & 8 & 10 & 13 \\
\hline Western porcupine-cover & r 87 & 90 & 80 & 87 & 90 & 82 \\
\hline grass -seed heads & 14 & 55 & 23 & 24 & 162 & 165 \\
\hline Sedge & 68 & 55 & 27 & 65 & 72 & 28 \\
\hline Smooth aster & 2 & 5 & 2 & 16 & 20 & 12 \\
\hline Bastard toad flax & 2 & 7 & 4 & 5 & 9 & 6 \\
\hline Yarrow & 1 & 3 & 2 & 3 & 6 & 4 \\
\hline Pussytoes & 1 & 2 & 0 & 5 & 7 & 2 \\
\hline Silverberry & 20 & 29 & 29 & 5 & 6 & 8 \\
\hline Rose & 6 & 11 & 13 & 9 & 10 & 9 \\
\hline Milk vetch ${ }^{2}$ & 4 & 8 & 6 & 2 & 2 & 1 \\
\hline Number of species & 30 & 30 & 27 & 29 & 28 & 28 \\
\hline May-August ppt (cm) & 29 & 18 & 28 & & & \\
\hline
\end{tabular}

'Agropyron trachycaulum and A. subsecundum.

'Astragalus agrestis, A. flexuosus and A. striatus.

\section{Discussion}

Rough fescue is a cool-season species that starts growth soon after snow melt. Spring fire is more detrimental than fall fire. Actively growing rough fescue plants appear to be more sensitive to fire damage than are dormant plants. Canopy coverage of rough fescue was reduced for at least 3 years when plants having $10 \mathrm{~cm}$ tall green growth were burned in spring, 1970. In contrast, the spring 1971 burn was conducted when green leaves were shorter. Coverage was reduced somewhat but annual production remained the same.

Weather, fuel, and soil moisture conditions are generally more favourable in spring than in fall for burning aspen forests and adjacent grasslands. However, the variable response of rough fescue to fire causes problems to the land manager who wants to conduct spring burns. In 1976, we observed $8 \mathrm{~cm}$ tall $\bar{n} \overline{\mathrm{W}} \overline{\mathrm{g}} \overline{\mathrm{g}} \overline{\mathrm{w}} \mathrm{w}$ th on south exposures and hilltops on April 15 when there was no growth on flat land there were still snow drifts in the adjacent aspen forest. We burned fireguards in the grassland on April 15 but could not burn the entire area until April 28 when understory fuels of the aspen forest had dried. Burns intense enough to kill trees and shrubs could be conducted from about April 25 to May 10 in most years. However, burning at this time would reduce production of rough rescue for 2 or 3 years. Prescribed burning of the grassland may have to be done in mid-April, followed 2 weeks later by burning of the aspen forest.

Johnston and MacDonald (1967) reported that seed set of the bunch type rough fescue of the southwestern Alberta foothills was determined during the August-September period of the previous growing season. Rough fescue does not produce seed heads every year but Johnston and MacDonald could find no factors responsible for induction and initiation of the floral primordia. Seed heads of rough fescue were not produced during 1970 but they were during 1971 in the unburned treatment. Seed heads were produced during the second growing season following the spring, 1970 burn (Burn 1). Therefore, burning 3 months prior to induction and initiation of the floral primordia did not affect seed head production of rough fescue. Density of seed heads was not reduced by the fall, 1970, burned treatment (Burn 2), which indicates burning immediately after induction of the floral primordia did not affect density of seed heads. The density of seed heads of rough fescue was greatly reduced in the spring, 1971, burned treatment (Burn 3). Johnston and MacDonald (1967) report that the average height of shoot apices above the root-stem transition was $12.6 \mathrm{~mm}$ in October and $39.6 \mathrm{~mm}$ in May of the following year. Thus, greater height of the shoot apices in May would make them more vulnerable to injury during the spring, 1971, fire. Rough fescue plants in the Central Alberta aspen parkland differ from the big bunchgrass of the Alberta foothills. Rough fescue in rhizomatous, shorter, and has smaller denser bunches of tillers than its counterpart in the Alberta foothills (Johnston and Cosby 1960). Shoot apices of the rhizomatous rough fescue are probably shorter in October and May than Johnston and McDonald (1967) found for the bunch type, but the principle probably still holds true.

The canopy coverage of western porcupine grass, a warmseason grass, was not affected by spring burning. At the same time, seed production was stimulated for at least 3 years. Smoliak and Johnston (1968) found that needleandthread (Stipa comata) seedlings had less leaf growth and produced fewer roots than rough fescue, at low temperatures. If the two Stipa species, western porcupine grass and needleandthread react similarly, their growing points would probably not be elevated as high as those of rough fescue at the time of a spring burn. Fall burning reduced canopy coverage and seed production of western porcupine grass. In Idaho, needleandthread was damaged by fall fire because the plant was still growing (Wright 1971). We did not determine the state of growth of western porcupine grass at the time of the fall burn.

Daubenmire (1968a) reported from many sources that burning favors forbs over grasses. This was the case when we burned grasslands. However, the favourable response was from perennial forbs rather than from annuals. Blue bur was the only annual that increased significantly in frequency and cover. The perennial forbs that responded quickly included three-flowered avens (Geum triflorum), milk vetch (Astragalus striatus), yarrow (Achillea millefolium), and pussytoes (Antennaria nitida). Not all broad-leaved plants were favoured by burning. The half-shrub fringed sage declined. Coupland (1973) found that an August wild fire in a wheatgrass community of the Mixed prairie in Saskatchewan reduced fringed sage. Fire shows promise as a potentially desirable means of reducing this unwanted increaser on Canadian rangelands.

Daubenmire (1968a) reported that burning increased both the quantity and availability of nutrients. The black surfaces absorb incoming radiation increasing soil temperature (Geiger 1966). Increased soil temperatures and increased nutrient supply are probably responsible for the temporary increase in frequency and cover of certain perennial forbs. The lack of an invasion of annual forbs the first year after a fire is probably not due to lack of a seed source. Johnston et al. (1969) found that the native prairie top soils had an abundant supply of viable seeds.

This grassland is well adapted to fire. The perennial forbs and grasses recover quickly after burning, not permitting effective competition from annuals. This is reflected by the high total 
canopy cover values of 250 to $280 \%$ the first growing season after fire. The adaptation of this grassland to fire is also reflected by the insignificant change in species diversity after burning.

The effect of fire on a rough-western porcupine grass community is complex and cannot be considered simply detrimental or beneficial. We did not experience a substantial decrease in total annual production for 3 years as found after a wild fire on a western wheatgrass-northern wheatgrass (Agropyron smithii-Agropyron dasystachyum) community of the Mixed Prairie (Coupland 1973). That burn occurred in late August when plants were still growing.

We burned in early October and early May when most plants were dormant. However, a sharp reduction occurred in canopy coverage of slender wheatgrass (Agropyron trachycaulum), bearded wheatgrass, ( $A$. subsecundum) and rough fescue after the May 3, 1970, burn when growth of these cool-season species was more advanced. Timing prescribed burns in the rough fescue-western porcupine grass community appears to be critical. Burning needs to be conducted as soon as possible after spring snow melt to minimize damage to rough fescue. Fall burning did not harm rough fescue but it does leave the grassland exposed to possible frost damage during winter.

\section{Summary and Conclusions}

The response of a rough fescue-western porcupine grass community to fire is complex. The effect of fire cannot be considered simply detrimental or beneficial. It varied according to stage of growth and season burned. Annual herbage production did not change after a spring or fall burn provided the plants were dormant. Total coverage of grass and grass-like plants decreased the first growing season after the burn. There was a corresponding increase in the canopy coverage of perennial forbs but no invasion by annuals. Spring burning caused a decline in the cover and seed production of cool-season grasses such as rough fescue. Fall burning reduced the coverage and seed production of western porcupine grass, a warm-season species. Spring burning when rough fescue was actively growing caused a decrease in its coverage for at least 3 years.

\section{Literature Cited}

Bailey, A.W., and R.A. Wroe. 1974. Aspen invasion in a portion of the Alberta parklands. J. Range Manage. 27: 263-266.

Clayton, J.S., W.A. Ehrlich, D.B. Cann, J.H. Day, and I.B. Marshall. 1977. Soils of Canada, Vol 1. Canada Agriculture, Ottawa. 243 p.

Coupland, R.T. 1973. Producers: I. Dynamics of above-ground standing crop. Matador Project, Canadian Int. Biol. Program. Tech. Rep. No. 27, Saskatoon, Sask. 159 p.

Coupland, R.T., and T.C. Brayshaw. 1953. The fescue grassland in Saskatchewan. Ecology 34: 386-405.

Daubenmire, R. 1968a. Ecology of fire in grasslands. Adv. Ecol. Res. 5: 209-266.

Daubenmire, R. 1968b. Plant Communities. A Textbook of Plant Synecology. Harper and Row. New York. 300 p.

Geiger, R. 1966. The Climate near the Ground. Harvard University Press. Cambridge, Mass. $611 \mathrm{p}$.

Johnston, A., and H.E. Cosby. 1960. Rhizomatous form of Festuca scabrella. Can. J. Plant Sci. 46: 411-212.

Johnston, A., and M.D. MacDonald. 1967. Floral initiation and seed production in Festuca scabrella Torr. Can. J. Plant Sci. 47: 577-583.

Johnston, A., and S. Smoliak. 1968. Reclaiming brushland in southwestern Alberta. J. Range Manage. 21: 404-406.

Johnston, A., S. Smoliak, and P.W. Stringer. 1969. Viable seed populations in Alberta prairie topsoils. Can. J. Plant Sci. 49: 75-82.

Maini, J.S. 1960. Invasion of grassland by Populus tremuloides in the Northern Great Plains. PhD thesis, Univ. of Saskatchewan, Canada. 231 p.

Moss, E.H. 1932. The vegetation of Alberta. IV. The poplar association and related vegetation of central Alberta. J. Ecol. 20: 380-415.

Mass, E.H. 1959. Flora of Alberta. Univ. of Toronto Press. Toronto. 546 p. Nelson, J.G., and R.E. England. 1971. Some comments on the causes and effects of fire in the northern grasslands area of Canada and the nearby United States, CA. 1750-1900. Can. Geog. 15: 295-306.

Scheffler, E.J. 1976. Aspen forest vegetation in a portion of the east central Alberta parklands. M.Sc. thesis. Univ. of Alberta, Edmonton. 160 p.

Smoliak, S., and A. Johnston. 1968. Germination and early growth of grasses at four root-zone temperations. Can. J. Plant Sci. 48: 119-127.

Wright, H.A. 1971. Why squirreltail is more tolerant to burning than needle-and-thread. J. Range Manage. 24: 277-284.

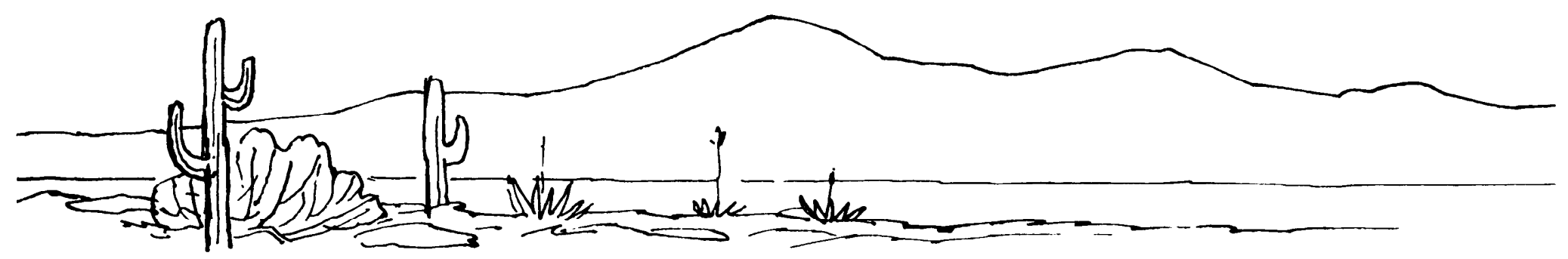

